\title{
PENGARUH PEMBERIAN F75 TERHADAP KENAIKAN BERAT BADAN BALITA DENGAN GIZI KURANG DI DESA TAMBAK CEMANDI KECAMATAN SEDATI SIDOARJO
}

\author{
Nyna Puspita Ningrum ${ }^{(1)}$ Indria Nuraini $^{(2)}$ Setiawandari $^{(3)}$ \\ Universitas PGRI Adi Buana Surabaya \\ Email : indria@unipasby.ac.id
}

\begin{abstract}
ABSTRAK
Anak Balita merupakan kelompok masyarakat rentan Gizi, yang mengalami siklus pertumbuhan dan perkembangan dengan kebutuhan Zat Gizi yang lebih besar. Faktor penyebab Gizi kurang secara tidak langsung disebabkan oleh tidak tercukupnya persediaan pangan di Rumah Tangga, Pola Asuh kurang memadai dan sanitasi/kesehatan lingkungan kurang baik serta akses pelayanan kesehatan terbatas. Upaya mengatasi masalah gizi kurang adalah dengan pemberian F75 (Formula Dosis F75) bertujuan untuk menaikkan berat badan. Tujuan penelitian ini adalah untuk mengetahui Pengaruh Pemberian F75 terhadap kenaikan berat badan balita dengan gizi kurang. Variabel Independen dalam penelitian ini adalah F75, sedangkan Variabel Dependen adalah kenaikan berat badan balita. Penelitian ini dilakukan di desa Tambak Cemandi, Kecamatan Sedati Sidoarjo pada tahun 2016. Populasi penelitian ini adalah Ibu dengan Balita Gizi kurang sebanyak 20 responden. Tehnik sampling yang digunakan Total sampling. Desain penelitian yang digunakan adalah Eksperimen. Uji statistik yang digunakan adalah Paired T Test.

Hasil Penelitian didapatkan Berdasarkan Hasil Uji Paired T Test didapatkan $P=0,000$ dengan $\alpha=0,05$, sehingga $P<\alpha$. Hasil Uji menunjukkan ada Pengaruh Pemberian F75 terhadap Kenaikan Berat Badan Balita dengan Gizi Kurang
\end{abstract}

Kata Kunci : Balita Gizi Kurang, F75, Kenaikan Berat Badan

\section{PENDAHULUAN}

Angka kematian anak di indonesia masih cukup tinggi yaitu 34/1.000 kelahiran hidup yang disebabkan oleh infeksi saluran pernapasan akut (ISPA), komplikasi perinatal dan diare. Pekerjaan Rumah kedua dari MDGs yaitu menanggulangi kemiskinan ekstrem dan kelaparan, masalah akibat kemiskinan berupa gizi buruk yang terjadi pada bayi dibawah lima tahun (balita) yang mencapai $80 \%$ anak pada keluarga miskin yang mempunyai pola makan tidak lengkap. (Riskesda 2013)

Gizi buruk merupakan suatu kondisi kekurangan nutrisi, atau nutrisinya kurang dari standar. Gizi buruk masih menjadi masalah yang belum terselesaikan dan banyak dialami oleh bayi dibawah lima tahun (balita). Masalah gizi merupakan masalah kesehatan masyarakat yang penanggulangannya tidak dapat dilakukan dengan pendekatan medis dan pelayanan kesehatan saja. Masalah gizi pada balita yang cukup besar dan mendapatkan prioritas penanganan adalah pada proporsi tertinggi pada kelompok umur 12 - 23 bulan dengan $8,2 \%$ untuk kategori sangat kurus (Riskesda, 2013). Di jawa timur masih terdapat 19,1\% angka kejadian Gizi kurang ataupun Gizi Buruk. Jumlah Balita di Desa Tambak Cemandi Sedati Sidoarjo $\pm 60-70$ balita dengan Usia 6 bulan sampai dengan 5 tahun. Berdasarkan hasil pengkajian data awal didapatkan bahwa dari 10 balita yang ditemukan 5 balita dengan Gizi Kurang. Salah satu hambatan belum turunnya angka kejadian Gizi kurang ataupun Gizi Buruk adalah pola asuh yang salah yang dilakukan oleh orang tua. Ada beberapa faktor yang mempengaruhi timbulnya Gizi Kurang/buruk merupakan faktor yang saling berkaitan baik secara langsung maupun tidak langsung, yaitu status sosial ekonomi, sanitasi lingkungan, pendidikan orang tua dan perilaku orang tua dalam mengasuh anak. 
Salah satu cara mengatasi Gizi buruk dapat dilakukan melalui suatu pendekatan kepada masyakat dengan pemberian diet untuk meningkatkan berat badan penderita Gizi kurang dan Gizi Buruk pada balita yaitu diet Formula WHO dengan dosis F75 (Depkes, 2007).

\section{METODE PENELITIAN}

Desain penelitian ini adalah Eksperimen. Lokasi penelitian ini dilakukan di Posyandu Desa Tambak Cemandi Kecamatan mulai bulan April - September 2017. Populasi Penelitian ini adalah keseluruhan balita dengan Gizi Kurang di Desa Tambak Cemandi, Kecamatan Sedati Sidoarjo sebanyak 20 responden dengan Tehnik Sampling Total Sampling. Analisis data pada penelitian ini yaitu dilakukan analisis dengan Paired T Test.

\section{HASIL PENELITIAN}

Hasil Penelitian yang dilaksanakan pada bulan April - September 2017 di Posyandu Desa Tambak Cemandi Sidoarjo adalah sebagai berikut :

1. Data Umum

a. Umur Ibu Balita

Tabel 1.1 Tabel Distribusi Frekuensi

berdasarkan Umur lbu

\begin{tabular}{|c|c|c|c|}
\hline \multirow{2}{*}{ No } & \multirow{2}{*}{ Umur } & \multicolumn{2}{|c|}{ Jumlah Responden } \\
\cline { 3 - 4 } & & Jumlah & $\begin{array}{c}\text { Frekuensi } \\
(\%)\end{array}$ \\
\hline 1 & $<20$ tahun & 0 & 0 \\
\hline 2 & $20-35$ tahun & 15 & 75 \\
\hline 3 & $>35$ tahun & 5 & 25 \\
\hline & Jumlah & 20 & 100 \\
\hline
\end{tabular}

Sumber : data primer, 2017

Berdasarkan tabel diatas

memperlihatkan sebagian besar

responden umur $20-35$ tahun

sebanyak 15 responden $(75 \%)$ dan

sebagian kecil $>35$ tahun sebanyak 5 responden (25\%).

b. Pendidikan Ibu Balita

Tabel 1.2 Tabel Distribusi Frekuensi

berdasarkan Pendidikan Ibu

\begin{tabular}{|c|c|c|c|}
\hline \multirow{2}{*}{ No } & \multirow{2}{*}{ Pendidikan } & \multicolumn{2}{|c|}{ Kelompok Kontrol } \\
\hline & & Jumlah & Frekuensi (\%) \\
\hline 1 & SD & 12 & 60 \\
\hline 2 & SMP & 3 & 15 \\
\hline 3 & SMA & 4 & 20 \\
\hline 4 & PT & 1 & 5 \\
\hline & Jumlah & 20 & 100 \\
\hline
\end{tabular}

Sumber : data primer, 2017

Berdasarkan tabel diatas

memperlihatkan sebagian besar responden pendidikan SD sebanyak 12 responden $(60 \%)$ dan sebagian kecil pendidikan Perguruan Tinggi (Diploma 3) sebanyak 1 responden (5\%).

c. Pekerjaan Ibu Balita

Tabel 1.3 Distribusi Frekuensi

berdasarkan Pekerjaan Ibu

\begin{tabular}{|c|l|c|c|}
\hline \multirow{2}{*}{ No } & \multicolumn{1}{|c|}{ Pekerjaan } & \multicolumn{2}{|c|}{ Kelompok Kontrol } \\
\cline { 3 - 4 } & & Jumlah & $\begin{array}{c}\text { Frekuensi } \\
(\%)\end{array}$ \\
\hline 1 & IRT & 18 & 90 \\
\hline 2 & Karyawan Pabrik & 2 & 10 \\
\hline 3 & Karyawan Swasta & 0 & 0 \\
\hline 4 & PNS & 0 & 0 \\
\hline \multicolumn{2}{|c|}{ Jumlah } & 20 & 100 \\
\hline
\end{tabular}

Sumber : data primer, 2017

Berdasarkan tabel diatas

memperlihatkan sebagian besar

pekerjaan ibu rumah tangga

sebanyak 18 responden (90\%) dan

sebagian kecil karyawan pabrik

sebanyak 2 responden (10\%)

d. Paritas/Status Persalinan Ibu

Tabel 1.4 Distribusi Frekuensi berdasarkan Paritas

\begin{tabular}{|c|c|c|c|}
\hline \multirow{2}{*}{ No } & \multirow{2}{*}{ Paritas } & Kumlah & $\begin{array}{c}\text { Frekuensi } \\
(\%)\end{array}$ \\
\cline { 3 - 4 } & & 7 & 35 \\
\hline 1 & Primipara & 13 & 65 \\
\hline 2 & Multipara & 0 & 0 \\
\hline 3 & Grandepara & 0 & 100 \\
\hline \multicolumn{2}{|c|}{ Jumlah } & 20 & \multicolumn{2}{|c|}{} \\
\hline
\end{tabular}

Sumber : data primer, 2017

Berdasarkan tabel diatas

memperlihatkan sebagian besar paritas ibu adalah multipara dengan jumlah anak 2 - 4 sebanyak 13 responden $(65 \%)$ dan sebagian kecil primipara dengan jumlah anak 1 sebanyak 7 responden (35\%).

2. Data Khusus
a. Data Balita
Tabel 1.5 Distribusi Frekuensi Balita dengan Gizi Kurang sebelum diberi F75 


\begin{tabular}{|l|c|c|c|}
\hline No & $\begin{array}{c}\text { Jenis } \\
\text { Kelamin }\end{array}$ & Umur & $\begin{array}{c}\text { Berat } \\
\text { Badan }\end{array}$ \\
\hline 1 & LK & 18 bulan & 8 \\
\hline 2 & PR & 36 bulan & 10 \\
\hline 3 & PR & 43 bulan & 9.5 \\
\hline 4 & LK & 24 bulan & 10.8 \\
\hline 5 & PR & 18 bulan & 8.4 \\
\hline 6 & LK & 7 bulan & 6.1 \\
\hline 7 & PR & 24 bulan & 8.8 \\
\hline 8 & PR & 12 bulan & 6.5 \\
\hline 9 & PR & 24 bulan & 10.8 \\
\hline 10 & LK & 16 bulan & 8.5 \\
\hline 11 & LK & 36 bulan & 12.8 \\
\hline 12 & PR & 13 bulan & 8.5 \\
\hline 13 & PR & 12 bulan & 7.7 \\
\hline 14 & LK & 14 bulan & 7.5 \\
\hline 15 & LK & 36 bulan & 10.5 \\
\hline 16 & PR & 18 bulan & 9 \\
\hline 17 & LK & 26 bulan & 7.2 \\
\hline 18 & PR & 19 bulan & 7.5 \\
\hline 19 & PR & 24 bulan & 9 \\
\hline 20 & LK & 36 bulan & 14 \\
\hline \multicolumn{3}{|c|}{ Sumber $:$ Data Primer 2017} \\
\hline
\end{tabular}

Sumber : Data Primer, 2017

Berdasarkan data diatas dapat diketahui bahwa rata-rata usia balita dengan Gizi kurang adalah 12-36 bulan dengan 9 responden jenis kelamin laki-laki dan 11 respoden dengan jenis kelamin perempuan dengan status Gizi kurus sampai dengan kurus sekali

b. Riwayat Pemberian ASI

Tabel 1.6 Distribusi Frekuensi berdasarkan Riwayat Pemberian ASI

\begin{tabular}{|c|c|c|c|}
\hline \multirow{2}{*}{ No } & \multirow{2}{*}{ Pemberian ASI } & \multicolumn{2}{|c|}{ Kelompok Kontrol } \\
\cline { 3 - 4 } & Jumlah & $\begin{array}{c}\text { Frekuensi } \\
(\%)\end{array}$ \\
\hline 1 & ASI Eksklusif & 4 & 20 \\
\hline 2 & $\begin{array}{c}\text { Tidak ASI } \\
\text { Eksklusif }\end{array}$ & 16 & 80 \\
\hline \multicolumn{2}{|c|}{ Jumlah } & 20 & 100 \\
\hline
\end{tabular}

Sumber : data primer, 2017

Berdasarkan tabel diatas memperlihatkan sebagian besar tidak diberikan ASI secara Eksklusif sebanyak 16 responden (80\%).

c. Riwayat Imunisasi

Tabel 1.7 Distribusi Frekuensi berdasarkan Riwayat Pemberian Imunisasi

\begin{tabular}{|c|c|c|c|}
\hline \multirow[b]{2}{*}{ No } & \multirow[b]{2}{*}{$\begin{array}{l}\text { Riwayat } \\
\text { Imunisasi }\end{array}$} & \multicolumn{2}{|c|}{ Kelompok Kontrol } \\
\hline & & Jumlah & $\begin{array}{c}\text { Frekuensi } \\
(\%)\end{array}$ \\
\hline 1 & Lengkap & 16 & 80 \\
\hline 2 & Tidak Lengkap & 4 & 20 \\
\hline \multicolumn{4}{|c|}{\begin{tabular}{l|c|} 
Jumlah & 20 \\
Sumher $\cdot$ data & 20 rimer 2017
\end{tabular}} \\
\hline & $\begin{array}{l}\text { Sumber : data } \\
\text { Berdasark } \\
\text { memperlihatk } \\
\text { mendapatkan } \\
\text { imunisasi } \\
\text { responden (8 }\end{array}$ & $\begin{array}{r}\text { rimer, } 20 \\
\text { tab } \\
\text { sebagia } \\
\text { munisasi } \\
\text { sar) se }\end{array}$ & $\begin{array}{ll} & \text { diatas } \\
\text { besar balita } \\
\text { lengkap } & (5 \\
\text { anyak } & 16\end{array}$ \\
\hline
\end{tabular}

d. Data Kenaikan Berat Badan Balita setelah diberikan F75

Tabel 1.8 Distribusi Frekuensi

Kenaikan Berat Badan Balita setelah diberi F75

\begin{tabular}{|c|c|c|c|}
\hline No & $\begin{array}{c}\text { Jenis } \\
\text { Kelamin }\end{array}$ & Umur & $\begin{array}{c}\text { Berat } \\
\text { Badan }\end{array}$ \\
\hline 1 & LK & 18 bulan & 9.9 \\
\hline 2 & PR & 36 bulan & 10.5 \\
\hline 3 & $\mathrm{PR}$ & 43 bulan & 10.8 \\
\hline 4 & LK & 24 bulan & 10.2 \\
\hline 5 & PR & 18 bulan & 8.8 \\
\hline 6 & LK & 7 bulan & 6 \\
\hline 7 & PR & 24 bulan & 10.1 \\
\hline 8 & PR & 12 bulan & 6.3 \\
\hline 9 & PR & 24 bulan & 11.8 \\
\hline 10 & LK & 16 bulan & 9.5 \\
\hline 11 & LK & 36 bulan & 13.8 \\
\hline 12 & PR & 13 bulan & 9.5 \\
\hline 13 & $\mathrm{PR}$ & 12 bulan & 8.1 \\
\hline 14 & LK & 14 bulan & 9 \\
\hline 15 & LK & 36 bulan & 11.5 \\
\hline 16 & PR & 18 bulan & 10.5 \\
\hline 17 & LK & 26 bulan & 8.2 \\
\hline 18 & $\mathrm{PR}$ & 19 bulan & 7.5 \\
\hline 19 & PR & 24 bulan & 9 \\
\hline 20 & LK & 36 bulan & 14 \\
\hline & \multicolumn{3}{|c|}{$\begin{array}{l}\text { Sumber: data primer, } 2017 \\
\text { Pada tabel diatas menunjukan } \\
\text { sebagian besar Berat Badan Balita } \\
\text { mengalami kenaikan sebanyak } 13 \\
\text { Responden }(65 \%) \text {. }\end{array}$} \\
\hline
\end{tabular}

e. Pengaruh Pemberian F75 terhadap Kenaikan Berat Badan Balita dengan Gizi Kurang

Tabel 5.6 Tabulasi Silang F75 terhadap Kenaikan Berat Badan di Desa Tambak Cemandi 


\begin{tabular}{|c|c|c|c|c|c|c|c|}
\hline & \multicolumn{4}{|c|}{ Kenaikan_BB } & \multirow[b]{2}{*}{ Total } & \multirow[b]{2}{*}{$\%$} \\
\hline & & $\begin{array}{l}\text { tidak } \\
\text { naik }\end{array}$ & $\%$ & Naik & $\%$ & & \\
\hline \multirow{2}{*}{ 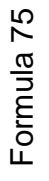 } & $\begin{array}{c}\text { tidak } \\
\text { F75 }\end{array}$ & 6 & 30 & 2 & 10 & 8 & 40 \\
\hline & F75 & 1 & 5 & 11 & 55 & 12 & 60 \\
\hline \multicolumn{2}{|c|}{ Total } & 7 & 7 & 35 & 13 & 65 & 20 \\
\hline
\end{tabular}

Berdasarkan Hasil Uji Paired T Test didapatkan 0,000 dengan $\alpha=0,05$, sehingga $P<a$. Hasil $U j i$ menunjukkan ada Pengaruh Pemberian F75 terhadap Kenaikan Berat Badan Balita dengan Gizi Kurang.

\section{PEMBAHASAN}

Karakteristik rerata Balita gizi kurang yaitu (1) balita yang tidak ASI Eksklusif mendapatkan makanan tambahan sejak lahir mulai berupa susu formula, bubur susu, sampai dengan nasi. Berdasarkan hasil penelitian diatas bahwa sebagian besar balita dengan gizi kurang disebabkan oleh tidak diberinya ASI Eksklusif, hal ini sesuai dengan teori bahwa Pemberian ASI dapat mencegah terjadinya malnutrisi pada anak. Semakin sering anak disusui mempunyai probabilitas yang lebih baik dari pada anak yang tidak disusui (Nasution, 2006) tetapi tidak hanya faktor Riwayat Pemberian ASI saja yang mempengaruhi Gizi Kurang di Desa Tambak Cemandi Surabaya tetapi ada faktor-faktor lain yang mempengaruhi yaitu Pengetahuan,

Pola Asuh, Sosial budaya dan Perilaku/Kebiasaan Ibu Balita yang dilakukan setiap hari, (2) Balita yang tidak mendapatkan imunisasi lengkap kekurangannya pada imunisasi campak dikarena balita sering sakit. Status Imunisasi dasar tidak lengkap beresiko terjadinya Gizi Kurang ataupun Gizi Buruk. Hal ini sesuai teori yang menyebutkan bahwa keadaan gizi yang buruk akan menurunkan fungsi system imun seperti makrofag dan limfosit sehingga mempengaruhi efektivitas imunisasi (Wahab,2002). Faktor lain yang menyebabkan balita tidak mendapatkan imunisasi lengkap adalah rendahnya tingkat pengetahuan ibu. Berdasarkan hasil penelitian diatas sebagian besar lbu balita dengan Pendidikan SD (60\%), (3) rerata usia balita 12-36 bulan, menurut Depkes (2001) jumlah tertinggi anak kurang gizi atau gizi buruk pada usia 12-23 bula, dikarenakan pada usia tersebut anak dalam masa pertumbuhan dan perkembangan dan pada tahap tersebut sering mengalami periode berkurangnya nafsu makan.

Rerata kenaikan berat badan balita antara sebelum dan setelah diberikan Formula 75 adalah 700 gram. Berdasarkan penelitian Sulistyawati, dkk didapatkan bahwa terdapat perbedaan peningkatan berat badan sebelum dan setelah diet antara yang diberi Formula 75 dan 100, dan kenaikan berat badan yang diberikan F75 lebih besar dibanding dengan yang diberikan F100 karena adanya perbedaan proporsi karakteristik usia pada responden. Evaluasi berat badan balita gizi buruk dinyatakan intervensi berhasil jika terdapat kenaikan berat badan $\geq 50$ gram $/ \mathrm{KgBB} /$ minggu (Depkes, 2007). Berdasarkan hasil penelitian diatas bahwa intervensi F75 dilakukan dalam jangka waktu 4 minggu dengan kenaikan berat badan rata-rata 700 gram. Sehingga dapat diartikan bahwa setiap minggu ada kenaikan sebesar $175 \mathrm{gram} / \mathrm{KgBB} /$ minggu maka diet F75 dapat meningkatkan berat badan balita gizi kurang sesuai standar yang diharapkan oleh Depkes.

Berdasarkan Hasil Penelitian didapatkan bahwa terdapat Pengaruh Pemberian F75 terhadap Kenaikan Berat Badan Balita dengan Gizi Kurang. Formula 75 diberikan dengan tujuan mengejar ketinggalan Berat Badan yang pernah dialami, mencapai berat badan normal sesuai dengan panjang badan serta agar tahap perkembangan kepandaian dan motoriknya sesuai umurnya. Kandungan Gizi Formula 75 yaitu 750 kal kalori, 9 gr Protein, $13 \mathrm{gr}$ laktosa, $36 \mathrm{mmol}$ kalium, $6 \mathrm{mmol}$ natrium, 4,3 mmol magnesium, $20 \mathrm{mg}$ seng, dan $2,5 \mathrm{mg}$ tembaga (Managemen Gizi Buruk, 2005) dan Formula 75 merupakan makanan cair yang mengandung tinggi kalori, protein dan cukup vitamin-mineral serta mudah untuk diserap. Variable Perancu (Confounding) dalam penelitian ini (Umur Ibu, Pendidikan, Pekerjaan, Paritas, Riwayat Pemberian ASI Eksklusif, dan Perilaku Sehari-hari) memberikan Kontribusi terhadap Kenaikan 
Berat Badan Balita Gizi Kurang di Desa Tambak Cemandi Sedati Sidoarjo. Semakin tinggi tingkat pendidikan, pengetahuan, dan keterampilan maka semakin baik tingkat ketahanan pangan keluarga, semakin baik pola pengasuhan anak dan keluarga maka semakin banyak memanfaatkan pelayanan yang ada. (Waryana, 2010). Menurut Soetjiningsih, jika pendidikan orang tua baik maka akan lebih mudah dalam menerima informasi dari luar.

\section{KESIMPULAN DAN SARAN}

\section{Kesimpulan}

Berdasarkan landasan teori dan didukung hasil Pengkajian data, maka dapat disimpulkan bahwa ada Pengaruh Pemberian F75 terhadap Kenaikan Berat Badan Balita dengan Gizi Kurang

\section{Saran}

Berdasarkan hasil penelitian ini dapat diberikan beberapa saran sebagai berikut :

a. Bagi kader posyandu maupun Bidan Desa Tambak Cemandi Sedati sidoarjo, perlu dilakukan kunjungan rumah secara kontinu untuk memantau dan memastikan perubahan perilaku

b. Kepada peneliti, lebih menerapkan ketentuan penelitian bagi responden dan kader posyandu sehingga lebih disiplin dan berkomitmen terhadap kegiatan ini.

\section{DAFTAR PUSTAKA}

Afriyanto, 2010. Keperawatan Keluarga dengan Kurang Gizi.Jakarta.EGC

CORE. 2004. Positive Deviance \& Hearth. Suatu Pendekatan Perubahan Perilaku \& Pos Gizi.Buku Panduan Pemulihan Yang Berkesinambungan Bagi Anak Malnutrisi. Jakarta. CORE.

Dahlia, S. 2014. Pengaruh Pendekatan PD terhadap Peningkatan Status Gizi Balita. Media Gizi Mayarakat Indonesia.

Ditjen Bina Gizi Dan Kesehatan Ibu Dan Anak Kementerian Kesehatan RI, 2011. Panduan Penyelenggaraan Pemberian Makanan Tambahan Pemulihan bagi
Balita Gizi Kurang (Bantuan Operasional kesehatan). Jakarta. Kementerian Kesehatan RI.

Depkes RI Direktorat Bina Gizi Masyarakat, 2008. Kegiatan Praktik Prilaku dan Pemulihan Gizi (KP3G) Melalui Pendekatan Positive Deviance. Modul Bagi Pelatih. Jakarta. FKM-UI.

Michelle, B. 20110. Maternal Education and child Nutritional Status in Bohvia.

Soetjiningsih, 2015. Tumbuh Kembang Anak Edisi 2. Jakarta. EGC

Supariasa, IDN. 2011. Penilaian Status Gizi (Edisi Revisi). Jakarta. EGC

Sulistyawati. 2011. Pengaruh Pemberian Diet Formula 75 dan 100 Terhadap Berat Badan Balita Gizi Buruk Rawat Jalan di Wilayah Kerja Puskesmas Pancoran Mas Kota Depok

Proverawati, A. 2011. Buku Ajar Gizi untuk Kebidanan. Jakarta. Nuha

Pelatihan TOT Fasilitator PKD bagi Fasilitator Gizi Kabupaten, Managemen Gizi Buruk. 2005.

Wahab A S, Madarina J. 2002. Sistem Imun, Imunisasi, \& Penyakit Imun. Jakarta: Widya Medika

Waryana (2010) Gizi Reproduksi. Yogyakarta: Pustaka Rihana.

www.litbang.depkes.go.id, 2013. Status Gizi. Jakarta. Riskesdas.

Widodo, R. 2009. Pemberian Makanan, Suplemen, dan Obat Pada Anak. Jakarta. EGC 